\title{
Ceramics
}

\section{Oxygen separation from air by the combined temperature swing and pressure swing processes using oxygen storage materials $\mathrm{Y}_{1-x}(\mathrm{~Tb} / \mathrm{Ce})_{x} \mathrm{MnO}_{3+\delta}$}

Alicja Klimkowicz ${ }^{1,2, *}$ (1) Takao Hashizume ${ }^{1}$, Kacper Cichy $^{3}$, Sayaka Tamura ${ }^{2}$, Konrad Świerczek ${ }^{3,4}$, Akito Takasaki ${ }^{1}$, Teruki Motohashi ${ }^{2}$, and Bogdan Dabrowski ${ }^{5}$

\author{
${ }^{1}$ Department of Engineering Science and Mechanics, Shibaura Institute of Technology, 3-7-5 Toyosu, Koto-ku, Tokyo 135-8548, \\ Japan \\ ${ }^{2}$ Department of Materials and Life Chemistry, Kanagawa University, Yokohama, Kanagawa 221-8686, Japan \\ ${ }^{3}$ Department of Hydrogen Energy, Faculty of Energy and Fuels, AGH University of Science and Technology, al. A. Mickiewicza 30, \\ 30-059 Krakow, Poland \\ ${ }^{4}$ AGH Centre of Energy, AGH University of Science and Technology, ul. Czarnowiejska 36, 30-054 Krakow, Poland \\ ${ }^{5}$ Institute of Physics, Polish Academy of Sciences, Aleja Lotnikow 32/46, 02-668 Warsaw, Poland
}

Received: 20 May 2020

Accepted: 23 August 2020

Published online:

31 August 2020

(C) The Author(s) 2020

\begin{abstract}
Hexagonal $\mathrm{Y}_{1-x} \mathrm{R}_{x} \mathrm{MnO}_{3+\delta}$ ( $\mathrm{R}$ : other than $\mathrm{Y}$ rare earth elements) oxides have been recently introduced as promising oxygen storage materials that can be utilized in the temperature swing processes for the oxygen separation and air enrichment. In the present work, the average and local structures of $\mathrm{Tb}$ - and Cesubstituted $\mathrm{Y}_{0.7} \mathrm{~Tb}_{0.15} \mathrm{Ce}_{0.15} \mathrm{MnO}_{3+\delta}$ and $\mathrm{Y}_{0.6} \mathrm{~Tb}_{0.2} \mathrm{Ce}_{0.2} \mathrm{MnO}_{3+\delta}$ materials were studied, and their oxygen storage-related properties have been evaluated. The fully oxidized samples show the presence of a significant amount of the highly oxygen-loaded the so-called Hex3 phase, attaining an average oxygen content of $\delta \approx 0.41$ for both compositions. Extensive studies of the temperature swing process conducted in air and $\mathrm{N}_{2}$ over the temperature range of $180-360{ }^{\circ} \mathrm{C}$ revealed large and reversible oxygen content changes taking place with only a small temperature differences and the high dependence on the oxygen partial pressure. Significant for practical performance, the highest reported for this class of compounds, oxygen storage capacity of $1900 \mu \mathrm{mol} \mathrm{O} \mathrm{g}{ }^{-1}$ in air was obtained for the optimized materials and swing process. In the combined temperature-oxygen partial pressure swing process, the oxygen storage capacity of $1200 \mu \mathrm{mol} \mathrm{O} \mathrm{g}{ }^{-1}$ was achieved.
\end{abstract}

Handling Editor: David Cann.

Address correspondence to E-mail: alicja@shibaura-it.ac.jp 


\section{Introduction}

In recent years, oxygen production has grown in importance because of the increasing demand from the industry and the health sectors. The oxygen-enriched gas is mainly utilized in the steel industry, welding, ammonia and methanol production, space technologies, cleaning of the wastewater, as well as oxygen therapy, and even oxygen as a recreation agent [1-4]. Besides conventional cryogenic-based oxygen production methods, alternative means using ceramic membranes are also gaining researchers' attention [5-7]. Another prospective method for oxygen production is the usage of the so-called oxygen storage materials (OSMs). These materials possess an ability to reversibly incorporate/release oxygen into/from their bulk crystal structure under specific conditions of temperatures and/or gas atmospheres.

Generally, two types of OSMs can be defined based on their valuable capability, the practically achievable oxygen content changes in the material. Firstly, the compounds that incorporate oxygen into their crystal lattice under oxidizing atmosphere (e.g., air or $\mathrm{O}_{2}$ ) and release it in reducing or ambient atmospheres (e.g., a mixture of $\mathrm{H}_{2}$ in $\mathrm{Ar}, \mathrm{N}_{2}$, etc.). The swing of oxygen partial pressure over the sample gave a name to the pressure swing absorption (PSA) process. Typically, the driving force for the oxygen incorporation/release requires changes in the oxygen partial pressure of several orders of magnitude [8]. Importantly, this process is different from the surface-related pressure swing absorption, which is commercially used in systems that operate with the active material utilizing its surface selectivity for air constituents [9-11]. The OSMs of PSA type have been widely known since the early 1980 s when the $\mathrm{CeO}_{2^{-}}$ based materials were firstly implemented in the three-way catalytic converters used in the exhaust system of gasoline-fueled vehicles [12, 13]. These OSMs work effectively as supporting catalysts to maintain the oxygen partial pressure in the exhaust gas at the desired level. They facilitate both, reduction of $\mathrm{NO}_{x}$ and oxidation of $\mathrm{CO}$ and unburned hydrocarbons (on the main catalyst). Despite the success of $\mathrm{CeO}_{2}$, search for better-performing OSMs is underway that exhibit improved thermal stability, even higher oxygen storage capacity (OSC), and show faster oxidation/reduction kinetics. Among the candidates are the so-called double perovskite materials from the $\mathrm{Y}_{1-x} \mathrm{R}_{x} \mathrm{BaMn}_{2} \mathrm{O}_{5+\delta}$ (R: other than $\mathrm{Y}$ rare earth elements) family that showed great potential for application [14-16]. Of the high practical importance, to eliminate the use of rare earth elements, is also the presented $\mathrm{Cu} / \mathrm{Mn}$-based stoichiometric spinel structure deposited on the $\mathrm{Nb} / \mathrm{Zr}$ oxide support [17]. In addition, owing to their intrinsic high oxygen ion mobility, some of them have been recently considered for application as the electrode materials in solid oxide fuel cells [18-21]. However, for the efficient reduction process of the PSA-type oxygen storage materials, the hydrogen-containing atmosphere is required. Because the released oxygen recombines with hydrogen to form water, these OSMs are not applicable for the oxygen production. While the usage of inert gas for reduction is possible in many cases, the slow kinetics of the process limits the practical application [22].

The second group of OSMs useful for oxygen production relies on large changes of the lattice oxygen content by relatively small variation of temperature at fixed oxygen partial pressure. This mode of operation is called the temperature swing absorption (TSA), as the driving force for the oxygen incorporation/release stems from the temperature changes only. These OSMs absorb and release oxygen at lower $\left(\leq T_{\text {oxy }}\right)$ and higher temperatures $\left(\geq T_{\text {red }}\right)$, respectively. The characteristic temperatures of $T_{\text {oxy }}$ and $T_{\text {red }}$ vary for different materials, while the general valued concern is to keep both temperatures quite low. However, when $T_{\text {oxy }}$ is too low, the kinetics of the oxidation reaction is too sluggish to achieve effective operation [23]. From a practical point of view, the temperature difference $\Delta T$ ( $T_{\text {red- }}$ $-T_{\text {oxy }}$ ) should also be as narrow as possible. A variety of materials have been tested regarding their applicability for TSA technology, including perovskite-type oxides such as (Ca,Sr) $\mathrm{MnO}_{3-\delta}$, $\mathrm{Sr}(\mathrm{Mn}, \mathrm{Fe}, \mathrm{Cu}) \mathrm{O}_{3-\delta}, \quad \mathrm{Ca}(\mathrm{Mn}, \mathrm{Fe}) \mathrm{O}_{3-\delta}, \quad \mathrm{YBaCO}_{4} \mathrm{O}_{7+\delta}$, $\mathrm{Ca}_{2} \mathrm{AlMnO}_{5+\delta}$ [24-27], as well as Co-Fe perovskite oxides with a general formula of $(\mathrm{La}, \mathrm{Sr})(\mathrm{Co}, \mathrm{Fe}) \mathrm{O}_{3-\delta}$ [28]. Unfortunately, the working temperatures of those materials are typically quite high, e.g., over $500{ }^{\circ} \mathrm{C}$ as required for efficient oxidation and $800{ }^{\circ} \mathrm{C}$ as required for the reduction of $\mathrm{La}_{0.1} \mathrm{Sr}_{0.9} \mathrm{Co}_{0.9} \mathrm{Fe}_{0.1} \mathrm{O}_{3-\delta}$ [29]. A promising material $\mathrm{YBaCo}_{4} \mathrm{O}_{7+\delta}$ oxidizes around $200{ }^{\circ} \mathrm{C}$ and reduces at $350{ }^{\circ} \mathrm{C}$ in oxygen, and therefore, $\Delta T$ is rather high [30]. The recently reported hexagonal $\mathrm{YMnO}_{3+\delta}$ 
compound and its derivatives $\left(\mathrm{Y}_{1-x} \mathrm{R}_{x} \mathrm{MnO}_{3+\delta}, \mathrm{R}\right.$ : other than $\mathrm{Y}$ rare earth elements) showed superior results in terms of the operating temperatures. Especially in the case of $\mathrm{Y}_{0.7} \mathrm{~Tb}_{0.3} \mathrm{MnO}_{3+\delta}$, very encouraging results have been obtained with $T_{\text {oxy- }}$ $\approx 270{ }^{\circ} \mathrm{C}$ in air with practical $\Delta T=60{ }^{\circ} \mathrm{C}$, while in oxygen the respective $T_{\text {oxy }} \approx 300^{\circ} \mathrm{C}$ and $T_{\text {red- }}$ $\approx 350{ }^{\circ} \mathrm{C}$ were required [31]. Substitution of $\mathrm{Tb}$ into $\mathrm{YMnO}_{3+\delta}$ allowed to significantly increase the maximum oxygen content in the oxidized phase, up to ca. 3.44 in an $\mathrm{O}_{2}$ atmosphere, as compared to ca. 3.27 for the pure $\mathrm{YMnO}_{3+\delta}$. A new phase of highly oxidized $\mathrm{Y}_{0.7} \mathrm{~Tb}_{0.3} \mathrm{MnO}_{3.45}$, described as Hex3 $\left(\mathrm{Pb}_{3} \mathrm{~cm}\right.$, $\delta \approx 0.45$ ), was discovered during those studies [31]. This phase supplemented the already-known series of phases with the excess oxygen contents: Hex2 $\left(P c a 2_{1} \delta \approx 0.41\right)$ and Hex1 $(R 3 c, \delta \approx 0.28)$, which are formed during the oxidation of the parent stoichiometric $\operatorname{Hex} 0\left(P 6_{3} m c, \delta \approx 0\right)$ [23, 31-34]. Additionally, among the chemically substituted $\mathrm{Y}_{1-x} \mathrm{R}_{x} \mathrm{MnO}_{3+\delta}$ phases studied, only the $\mathrm{Y}_{0.7} \mathrm{~Tb}_{0.3} \mathrm{MnO}_{3+\delta}$ showed acceptable performance in air atmosphere (OSC $\approx$ $1.8 \mathrm{wt} \%)$, making it a very attractive candidate for the oxygen separation technology. An improvement of the oxygen storage characteristics was achieved by suitable morphological modifications. For example, the $\mathrm{YMnO}_{3+\delta}$ nanoparticles showed ca. $1.5 \mathrm{wt} \%$ capacity in air. The fabrication of nanoparticles increased the specific surface area accessible for the oxygen reduction and reduced the diffusion lengths, both of which resulted in a significantly better performance [35].

In this work, further attempts were made, aiming at improvement of the oxygen production and storage-related operation in air, which were based on a partial substitution of $\mathrm{Y}^{3+}$ in $\mathrm{Y}_{1-x} \mathrm{R}_{x} \mathrm{MnO}_{3+\delta}$ with larger $\mathrm{Tb}^{3+}$ and simultaneously by cerium, which may be present either at the +3 or +4 valence state (the relevant ionic radii for the eightfold coordination are: $r_{\mathrm{Y} 3+}=1.019 \AA, r_{\mathrm{Tb} 3+}=1.040 \AA, r_{\mathrm{Ce} 3+}=1.143 \AA$, $r_{\mathrm{Ce} 4+}=0.970 \AA$ [36]). The crystal structure and microstructure of $\mathrm{Y}_{0.7} \mathrm{~Tb}_{0.15} \mathrm{Ce}_{0.15} \mathrm{MnO}_{3+\delta}$ and $\mathrm{Y}_{0.6-}$ $\mathrm{Tb}_{0.2} \mathrm{Ce}_{0.2} \mathrm{MnO}_{3+\delta}$ oxides were characterized in the reduced and oxidized states. Samples were examined in terms of their suitability for temperature swing absorption (TSA) and oxygen partial pressure swing absorption (PSA) processes, as well as in the combined temperature/pressure swing absorption (TPSA) route.

\section{Experimental details}

Hexagonal $\mathrm{Y}_{0.7} \mathrm{~Tb}_{0.15} \mathrm{Ce}_{0.15} \mathrm{MnO}_{3+\delta}$ and $\mathrm{Y}_{0.6} \mathrm{~Tb}_{0.2-}$ $\mathrm{Ce}_{0.2} \mathrm{MnO}_{3+\delta}$ materials were prepared using a selfcombustion-type method, with respective nitrates initially dissolved in a stoichiometric proportion in deionized water. EDTA dissolved in diluted ammonia was added as a complexing agent. The mixture was then heated in a mantle heater up to $400{ }^{\circ} \mathrm{C}$ in air, which allowed for evaporation of water, as well as the removal of nitrogen and carbon during the selfcombustion stage. The obtained precursor was crushed in a mortar and pressed into pellets. The actual synthesis was carried out at $1000{ }^{\circ} \mathrm{C}$ for $8 \mathrm{~h}$ in Ar gas flow, which is known to promote the formation of the desired hexagonal structure [37]. Initially, the sintered samples were taken out from a warm furnace and exposed to the atmospheric air, which caused partial oxidation (see the discussion below). The route utilized in this study enables synthesis at relatively low temperatures in comparison with the standard solid-state reaction method [32, 38]. More details regarding the preparation procedure can be found elsewhere [31-33].

Structural X-ray diffraction (XRD) studies were conducted on Panalytical Empyrean or Rigaku SmartLab diffractometers. The measurements were carried out in a $10-110$ deg range using $\mathrm{Cu}_{\mathrm{K} \alpha}$ radiation. The structural analysis was performed by the Rietveld method using GSAS/EXPGUI software [39, 40].

Morphology of the samples was investigated using a JEOL JSM-7100F scanning electron microscope (SEM) equipped with energy-dispersive $X$-ray spectroscopy (EDS) detector, which was used to confirm the chemical homogeneity of the samples. High-resolution transmission electron microscopy (TEM) imaging was conducted using a JEOL JEM-2100 field emission electron microscope, operated at an accelerating voltage of $200 \mathrm{kV}$. The specific surface area tests were conducted by the $\mathrm{N}_{2}$ adsorption method using a BELSORP MINI II apparatus. About $0.5 \mathrm{~g}$ of the powdered material was used in the experiments. Data were analyzed assuming Brunauer-EmmettTeller (BET) isotherm.

The studies of X-ray photoelectron spectroscopy (XPS) were performed using PHI 5000 VersaProbe II, supplied by ULVAC-PHI, Inc. Japan, to elaborate on the oxidation state of the constituent elements. The survey spectra for $\mathrm{Y}_{0.7} \mathrm{~Tb}_{0.15} \mathrm{Ce}_{0.15} \mathrm{MnO}_{3+\delta}$ were 
measured in a $0-1100 \mathrm{eV}$ binding energy range at room temperature, with a monochromatic $\mathrm{Mg} \mathrm{K \alpha}$ $\mathrm{X}$-ray $(1253.6 \mathrm{eV})$ as an excitation source.

The oxygen storage-related performance of the materials was evaluated using the thermogravimetric (TG) technique. The temperature swing and pressure swing measurements were carried out using a TA Q5000 IR apparatus. Initially, a temperature swing experiment was performed in air with a relatively slow heating rate of $1{ }^{\circ} \mathrm{C} \mathrm{min}{ }^{-1}$ to achieve the lowest and highest oxygen contents of the studied sample. The consecutive heating and cooling up to $800-850{ }^{\circ} \mathrm{C}$ with a ramp of $5{ }^{\circ} \mathrm{C} \mathrm{min}^{-1}$ were applied after switching the gas to argon to reduce the sample completely. Additional experiments up to ca. $900{ }^{\circ} \mathrm{C}$ (not reported here) revealed a stable weigh above $800{ }^{\circ} \mathrm{C}$, indicating that the material attains its oxygen stoichiometric composition $(\delta \approx 0)$. The temperatures of oxidation and reduction $\left(T_{\text {oxy }}, T_{\text {red }}\right)$ were determined as read-off extrema from the first-order derivative graphs.

TSA experiments were conducted at varying temperatures in the range of $190-360{ }^{\circ} \mathrm{C}$ in air. Furthermore, as the speeds of the oxidation and reduction processes are different, the reaction durations needed to be optimized to achieve the highest OSC. As the oxidation takes place at lower temperatures, the oxidation rate is generally lower than the reduction rate (at higher temperatures). After testing different conditions, the optimized oxidation time was selected as $45 \mathrm{~min}$, while $15 \mathrm{~min}$ was adequate for the reduction. The PSA experiments were conducted upon switching the gas atmosphere between air and $\mathrm{N}_{2}\left(99.999 \%\right.$ pure, $\left.<2 \mathrm{ppm} \mathrm{O}_{2}\right)$ at $254{ }^{\circ} \mathrm{C}$ and $241{ }^{\circ} \mathrm{C}$ for $\mathrm{Y}_{0.7} \mathrm{~Tb}_{0.15} \mathrm{Ce}_{0.15} \mathrm{MnO}_{3+\delta}$ and $\mathrm{Y}_{0.6} \mathrm{~Tb}_{0.2} \mathrm{Ce}_{0.2} \mathrm{MnO}_{3+\delta}$, respectively, at which the maximum oxygen contents were registered upon heating at $1{ }^{\circ} \mathrm{C} \mathrm{min}^{-1}$ in air (indicated in Fig. 3a, b).

Additionally, the combined TSA and PSA tests were conducted using a Rigaku Thermo plus EVO2 TG-DTA8122 device. The temperatures were set at $220{ }^{\circ} \mathrm{C}$ for the oxidation and $360^{\circ} \mathrm{C}$ for the reduction. These temperatures yielded the highest capacity in the TSA studies for $\mathrm{Y}_{0.7} \mathrm{~Tb}_{0.15} \mathrm{Ce}_{0.15} \mathrm{MnO}_{3+\delta}$. The oxygen partial pressure swing was applied simultaneously by the gas change between $\mathrm{N}_{2}$ (99.999\% pure) and $\mathrm{O}_{2}$ or air. Prior to every TG run, the samples were reduced in $\mathrm{Ar}$ at $800^{\circ} \mathrm{C}$ to completely remove excess oxygen $(\delta \approx 0)$ and thereby to ensure accurate oxygen content measurements. The absence of excess oxygen in the treated samples was further confirmed by room temperature XRD, in which no trace of the oxidized phases was evidenced.

\section{Results and discussion}

\section{Samples characterization and structural studies}

As presented in Fig. 1a, the as-synthesized samples of the hexagonal $\mathrm{Y}_{0.7} \mathrm{~Tb}_{0.15} \mathrm{Ce}_{0.15} \mathrm{MnO}_{3+\delta}$ and $\mathrm{Y}_{0.6-}$ $\mathrm{Tb}_{0.2} \mathrm{Ce}_{0.2} \mathrm{MnO}_{3+\delta}$ materials showed some oxygen excess $(\delta>0)$, which can be concluded from the presence of both the Hex0 $(\delta \approx 0)$ and Hex1 $(\delta \approx 0.28)$ phases in XRD patterns. By using Rietveld refined phase weight ratios and the previously
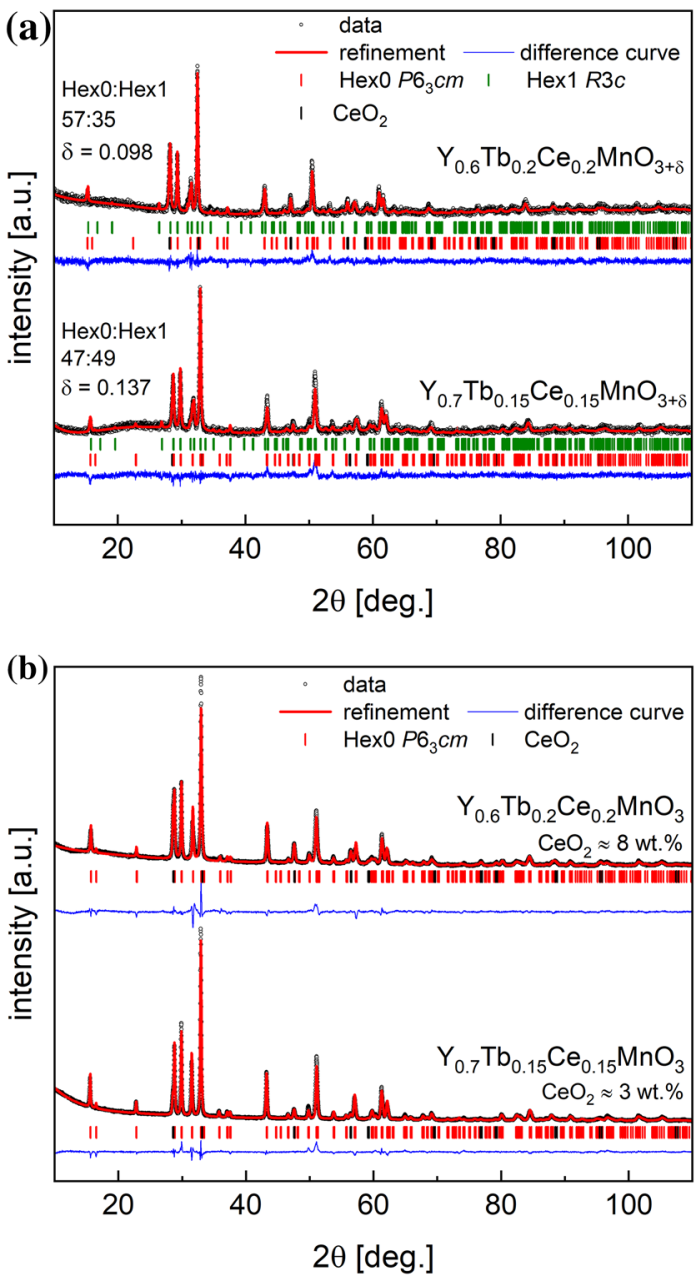

Figure 1 Room temperature $\mathrm{XRD}$ data with refinement for $\mathrm{Y}_{0.7} \mathrm{~Tb}_{0.15} \mathrm{Ce}_{0.15} \mathrm{MnO}_{3+\delta}$ and $\mathrm{Y}_{0.6} \mathrm{~Tb}_{0.2} \mathrm{Ce}_{0.2} \mathrm{MnO}_{3+\delta}:$ a assynthesized, and $\mathbf{b}$ after reduction at $800{ }^{\circ} \mathrm{C}$ in $\mathrm{Ar}$ flow. 
established oxygen contents [23], the average oxygen excess was found to be 0.137 for $\mathrm{Y}_{0.7} \mathrm{~Tb}_{0.15} \mathrm{Ce}_{0.15}$ $\mathrm{MnO}_{3+\delta}$ and 0.098 for $\mathrm{Y}_{0.6} \mathrm{~Tb}_{0.2} \mathrm{Ce}_{0.2} \mathrm{MnO}_{3+\delta}$. The oxygen contents derived from the XRD data are in good agreement with those obtained from the thermogravimetric measurements presented below. Additional heat treatment at $800{ }^{\circ} \mathrm{C}$ for $5 \mathrm{~h}$ in Ar gas flow was found to reduce the samples, with both materials containing only the $\operatorname{Hex} 0$ structure $(\delta \approx 0)$ contaminated by the same small amount of $\mathrm{CeO}_{2}$ (Fig. 1b). The XRD-derived structural parameters of the constituent phases are presented in Table 1. Noticeably, the impurity $\mathrm{CeO}_{2}$ does not change the oxygen content in Ar between 1000 and $800{ }^{\circ} \mathrm{C}$ [41]. It should be mentioned that the synthesis of singlephase $\mathrm{Y}_{0.6} \mathrm{~Tb}_{0.4-x} \mathrm{Ce}_{x} \mathrm{MnO}_{3}$ was successful up to $x=0.2$ for samples fired at higher temperatures of $1400{ }^{\circ} \mathrm{C}$ (not reported in this work). However, the materials obtained in this way were not suitable for oxygen storage studies due to their limited specific surface areas.

Comparing the published structural data for nearly oxygen-stoichiometric $\mathrm{YMnO}_{3}$ [31] and the $\mathrm{Tb}^{3+}$-for$\mathrm{Y}^{3+}$ substituted $\mathrm{Y}_{0.7} \mathrm{~Tb}_{0.3} \mathrm{MnO}_{3}[32]$, it can be noticed that the reduced $\mathrm{Tb}$-containing material (Hex0 phase) exhibits larger values of the cell parameter $a$, while smaller values of the $c$ parameter, and overall the unit cell volume is considerably larger than for the parent $\mathrm{YMnO}_{3}$ (Table 1). The difference is significant and matches with bigger $\mathrm{Tb}^{3+}$ in relation to smaller $\mathrm{Y}^{3+}$ at the same crystal coordination. In the case of Ce-containing materials, it is necessary to reduce them (in Ar) to get the oxygen content close to the stoichiometric one. In this case, a significant part of Ce species has to be at +3 oxidation state, as the unit cell volume for the reduced $\mathrm{Y}_{0.7} \mathrm{~Tb}_{0.15} \mathrm{Ce}_{0.15} \mathrm{MnO}_{3}$ and $\mathrm{Y}_{0.6} \mathrm{~Tb}_{0.2} \mathrm{Ce}_{0.2} \mathrm{MnO}_{3}$ is even larger. $\left(\mathrm{Ce}^{4+}\right.$ is smaller than $\mathrm{Y}^{3+}$, while $\mathrm{Ce}^{3+}$ is larger even than $\mathrm{Tb}^{3+}$ in the same coordination.) Notably, the unit cell volume of $\mathrm{Y}_{0.6} \mathrm{~Tb}_{0.2} \mathrm{Ce}_{0.2} \mathrm{MnO}_{3}$ is somewhat smaller than that of $\mathrm{Y}_{0.7} \mathrm{~Tb}_{0.15} \mathrm{Ce}_{0.15} \mathrm{MnO}_{3}$, which is likely related to the amount of $\mathrm{CeO}_{2}$ contamination present in the samples.

The SEM micrographs of the as-synthesized samples are presented in Fig. 2a, b. The insets show micrographs taken at higher magnifications, which allowed to conclude that the size of primary grains is in the order of hundreds of nanometers. The particles form relatively loosely adhered aggregates and agglomerates. Both samples seem to have a highly

Table 1 Structural parameters of the $\mathrm{Y}_{0.7} \mathrm{~Tb}_{0.15} \mathrm{Ce}_{0.15} \mathrm{MnO}_{3+\delta}$ and $\mathrm{Y}_{0.6} \mathrm{~Tb}_{0.2} \mathrm{Ce}_{0.2} \mathrm{MnO}_{3+\delta}$ materials as-synthesized and after additional reduction in $\mathrm{Ar}$

\begin{tabular}{|c|c|c|c|c|c|c|}
\hline Sample & Phases content $(w t \%)$ & $a(\AA)$ & $c(\AA)$ & $V\left(\AA^{3}\right)$ & $R_{w p}(\%)$ & $\chi^{2}$ \\
\hline \multirow[t]{4}{*}{ As-synthesized $\mathrm{Y}_{0.7} \mathrm{~Tb}_{0.15} \mathrm{Ce}_{0.15} \mathrm{MnO}_{3+\delta}^{\mathrm{a}}$} & Hex0 & $6.1961(3)$ & $11.2636(10)$ & $374.49(5)$ & \multirow[t]{4}{*}{9.65} & \multirow[t]{4}{*}{1.34} \\
\hline & 47 & & & & & \\
\hline & Hex1 & 6.2075 & $33.5454(27)$ & $1119.44(12)$ & & \\
\hline & 49 & & & & & \\
\hline \multirow[t]{4}{*}{ As-synthesized $\mathrm{Y}_{0.6} \mathrm{~Tb}_{0.2} \mathrm{Ce}_{0.2} \mathrm{MnO}_{3+\delta}^{\mathrm{b}}$} & Hex0 & $6.195(3)$ & $11.2111(22)$ & $372.68(4)$ & \multirow[t]{4}{*}{9.99} & \multirow[t]{4}{*}{1.23} \\
\hline & 57 & & & & & \\
\hline & Hex1 & $6.2027(3)$ & $33.481(25)$ & $1114.12(11)$ & & \\
\hline & 35 & & & & & \\
\hline \multirow[t]{2}{*}{ Reduced $\mathrm{Y}_{0.7} \mathrm{~Tb}_{0.15} \mathrm{Ce}_{0.15} \mathrm{MnO}_{3}^{\mathrm{a}}$} & Hex0 & $6.1901(1)$ & $11.3428(2)$ & $376.40(1)$ & \multirow[t]{2}{*}{3.1} & \multirow[t]{2}{*}{4.782} \\
\hline & 97 & & & & & \\
\hline \multirow[t]{2}{*}{ Reduced $\mathrm{Y}_{0.6} \mathrm{~Tb}_{0.2} \mathrm{Ce}_{0.2} \mathrm{MnO}_{3}^{\mathrm{b}}$} & Hex0 & $6.1996(1)$ & $11.3006(1)$ & $376.15(1)$ & \multirow[t]{2}{*}{3.6} & \multirow[t]{2}{*}{6.187} \\
\hline & 92 & & & & & \\
\hline $\mathrm{Y}_{0.7} \mathrm{~Tb}_{0.3} \mathrm{MnO}_{3}^{\mathrm{c}}$ & Hex0 & $6.1612(1)$ & $11.4143(2)$ & $375.12(1)$ & 6.5 & 1.529 \\
\hline $\mathrm{YMnO}_{3}^{\mathrm{d}}$ & Hex0 & $6.1486(1)$ & 11.3898 (1) & $372.91(1)$ & 1.8 & 2.209 \\
\hline
\end{tabular}

Both materials contain $\mathrm{CeO}_{2}$ contamination, as presented in Fig. $1 \mathrm{~b}$ in an amount

${ }^{\mathrm{a}} 3 \mathrm{wt} \%$

b 8 wt $\%$

${ }^{\mathrm{c}}$ Data from [31]

${ }^{\mathrm{d}}$ Data from [32] 
developed surface, which was confirmed with BET tests. The values for the specific surface area were $12.9 \mathrm{~m}^{2} \mathrm{~g}^{-1}$ and $9.33 \mathrm{~m}^{2} \mathrm{~g}^{-1}$ for $\mathrm{Y}_{0.7} \mathrm{~Tb}_{0.15} \mathrm{Ce}_{0.15-}$ $\mathrm{MnO}_{3+\delta}$ and $\mathrm{Y}_{0.6} \mathrm{~Tb}_{0.2} \mathrm{Ce}_{0.2} \mathrm{MnO}_{3+\delta}$, respectively. For comparison, the $\mathrm{YMnO}_{3+\delta}$ obtained by the sol-gel method and sintered at $1100{ }^{\circ} \mathrm{C}$ showed a specific surface area of $7.2 \mathrm{~m}^{2} \mathrm{~g}^{-1}$ [32]. The higher specific surface area registered for the $\mathrm{Tb}$-/Ce-substituted samples originates from the lower sintering temperature of $1000{ }^{\circ} \mathrm{C}$ in comparison with the reference $\mathrm{YMnO}_{3+\delta}$ material sintered at $1100{ }^{\circ} \mathrm{C}$. Since the oxygen intake/release proceeds with many steps, and it also involves adsorption/desorption and reduction/oxidation, and therefore, the highly developed surface through which the process proceeds improves the kinetics of the observed reactivity with oxygen [31]. If materials possess similar BET specific surface areas, the differences in the measured kinetic characteristics can be interpreted to arise mainly from the difference in the chemical composition of the compounds.

The TEM studies (Fig. 2c) revealed good crystallinity of the samples, as well as allowed to confirm the presence of the Hex0 phase in the reduced $\mathrm{Y}_{0.7}$ $\mathrm{Tb}_{0.15} \mathrm{Ce}_{0.15} \mathrm{MnO}_{3}$. The high-resolution images taken at two different areas showed the presence of lattice fringes, which were identified as originating from the (110) and (004) planes.

\section{Oxygen storage properties}

To determine the characteristic temperatures of oxygen incorporation/release, the samples were systematically tested on a thermogravimetric device. The initial oxygen content in $\mathrm{Y}_{0.7} \mathrm{~Tb}_{0.15} \mathrm{Ce}_{0.15} \mathrm{MnO}_{3+\delta}$ and $\mathrm{Y}_{0.6} \mathrm{~Tb}_{0.2} \mathrm{Ce}_{0.2} \mathrm{MnO}_{3+\delta}$ registered in TG measurements (Fig. 3) is in agreement with the oxygen level calculated based on the XRD data (Fig. 1). As can be seen in Fig. 3a, b, the weight of the as-synthesized samples during slow heating $\left(1{ }^{\circ} \mathrm{C} \mathrm{min}^{-1}\right)$ in air initially increases and then decreases. The data indicate the oxidation of the nearly stoichiometric phase obtained in Ar, with a weight change corresponding to the oxygen content increase exceeding 0.35 and then the reduction (oxygen release) at higher temperatures. The oxygen content in the samples was determined under the assumption that the stable weight at ca. $800{ }^{\circ} \mathrm{C}$ in $\mathrm{Ar}$ corresponds to the oxygen-stoichiometric composition. The Hex 0 phase $(\delta \approx 0)$ of hexagonal oxides is stable at high temperatures, as it
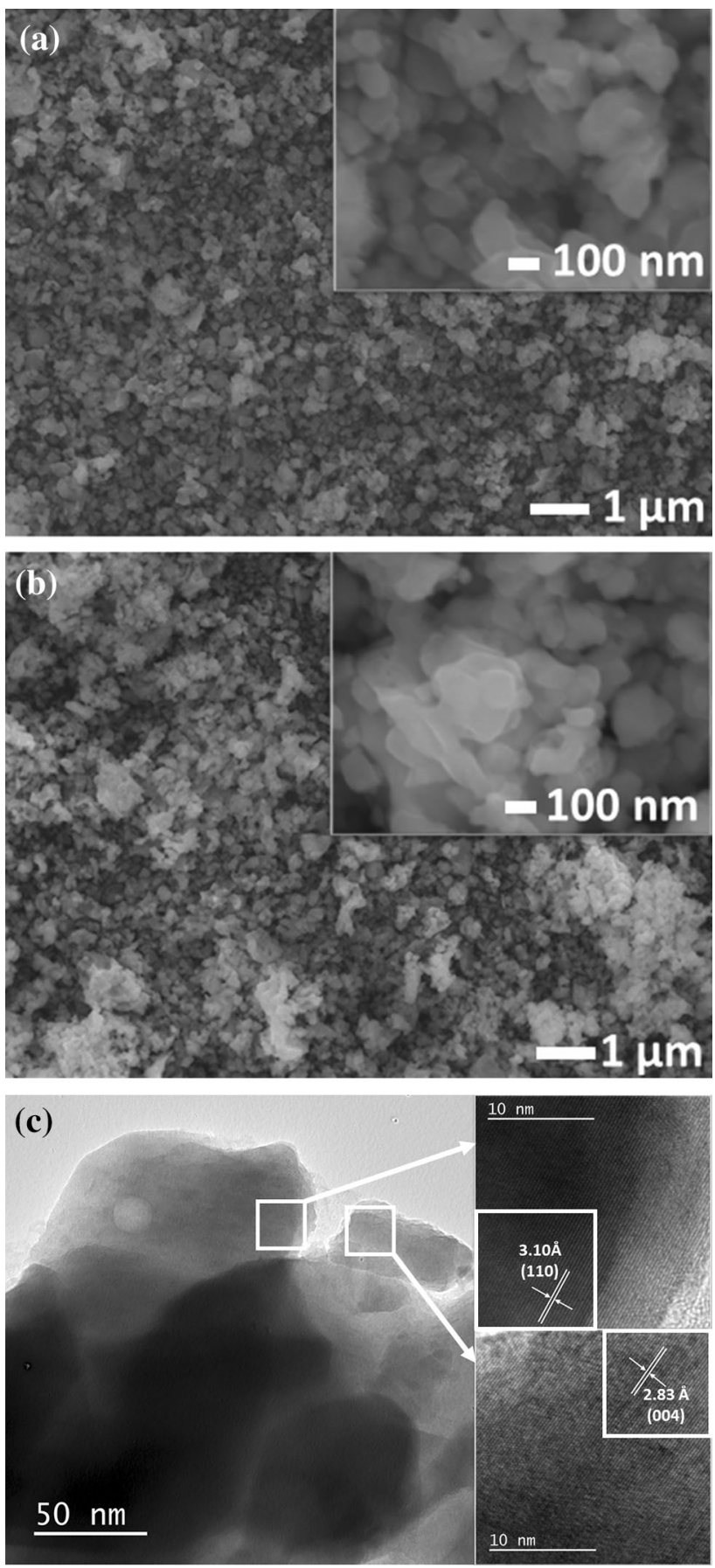

Figure 2 SEM micrographs of as-synthesized a $\mathrm{Y}_{0.7} \mathrm{~Tb}_{0.15} \mathrm{Ce}_{0.15} \mathrm{MnO}_{3+\delta}$ and $\mathbf{b} \quad \mathrm{Y}_{0.6} \mathrm{~Tb}_{0.2} \mathrm{Ce}_{0.2} \mathrm{MnO}_{3+\delta}$ at different magnifications. c TEM bright-field image of the reduced $\mathrm{Y}_{0.7} \mathrm{~Tb}_{0.15} \mathrm{Ce}_{0.15} \mathrm{MnO}_{3}$ with the selected areas observed using a high-resolution mode. The calculated d-spacings correspond to (110) and (004) planes of the Hex0 phase.

was already documented in all other papers devoted to studies of this class of materials [23, 31-33]. Because the substituted cerium tends to have +4 

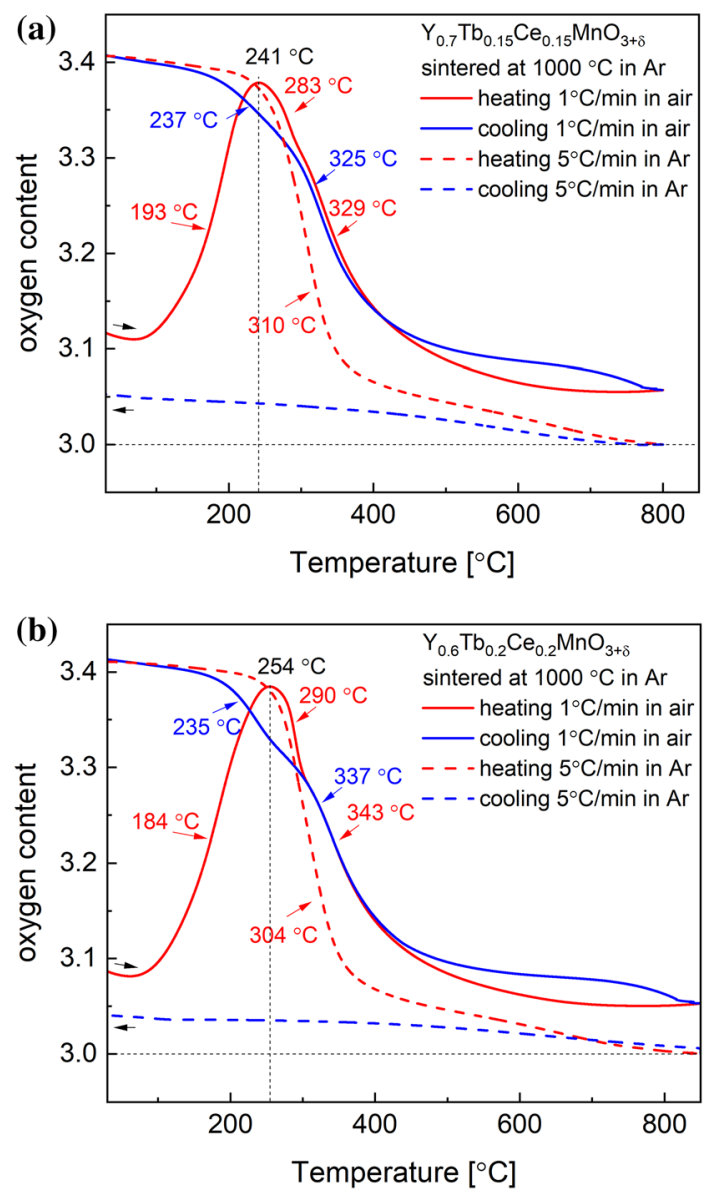

Figure 3 Temperature dependence of the oxygen content registered during heating and cooling for a $\mathrm{Y}_{0.7} \mathrm{~Tb}_{0.15} \mathrm{Ce}_{0.15} \mathrm{MnO}_{3+\delta}$ and $\mathbf{b} \mathrm{Y}_{0.6} \mathrm{~Tb}_{0.2} \mathrm{Ce}_{0.2} \mathrm{MnO}_{3+\delta}$. The measurements were conducted in air and $\mathrm{Ar}$ atmospheres with scan rates of 1 and $5{ }^{\circ} \mathrm{C} \mathrm{min}{ }^{-1}$. The characteristic temperatures of oxidation and reduction, as well as the temperature of maximum oxygen content during heating in air (later utilized in PSA studies), are indicated in the figure.

oxidation state in air, the considered compounds show rather a mixture of the oxidized Hex1 and Hex0 phases, unless properly reduced, e.g., in Ar (Table 1). It is evident that both materials show oxygen excess even at $800{ }^{\circ} \mathrm{C}$ in air, indicating the strong oxygen affinity due to Ce substitution. Also, some oxidation was visible on cooling even in $5 \mathrm{~N}$ pure argon. (The buoyancy effect was assumed as negligible.) This makes them promising materials for oxygen scavengers.

Since there are visible inflections present on the TG curves recorded in air (Fig. 3), determination of the characteristic temperatures of oxidation and reduction is somewhat hindered. The location of one of the inflections in the vicinity of $\delta \approx 0.28$ seems to correspond to the formation of the Hex1 phase and indicates its relatively high stability. Likely, at lower temperatures in air, both materials consist of mixtures of the Hex1 and Hex3 phases (Fig. 4, Table 2), while at higher temperatures the Hex0 and Hex1 phases coexist. However, this conjecture requires some further in situ structural studies at high temperatures.

The temperature readouts of the particular processes are placed in Fig. 3 and are color-coded. For the $\mathrm{Y}_{0.6} \mathrm{~Tb}_{0.2} \mathrm{Ce}_{0.2} \mathrm{MnO}_{3+\delta}$ sample, the oxidation occurs at lower temperatures, while the reduction is registered at higher temperatures than in $\mathrm{Y}_{0.7} \mathrm{~Tb}_{0.15}$ $\mathrm{Ce}_{0.15} \mathrm{MnO}_{3+\delta}$. A narrower working temperature range for $\mathrm{Y}_{0.7} \mathrm{~Tb}_{0.15} \mathrm{Ce}_{0.15} \mathrm{MnO}_{3+\delta}$ is advantageous to prospective practical applications. Interestingly, the temperature of the maximum oxygen content upon heating with $1{ }^{\circ} \mathrm{C} \mathrm{min}^{-1}$ was registered to be $241^{\circ} \mathrm{C}$ for $\mathrm{Y}_{0.7} \mathrm{~Tb}_{0.15} \mathrm{Ce}_{0.15} \mathrm{MnO}_{3+\delta}$, and $254{ }^{\circ} \mathrm{C}$ for $\mathrm{Y}_{0.6} \mathrm{~Tb}_{0.2-}$ $\mathrm{Ce}_{0.2} \mathrm{MnO}_{3+\delta}$, which is significantly lower than $289{ }^{\circ} \mathrm{C}$ measured under the same conditions for the $\mathrm{Y}_{0.7} \mathrm{~Tb}_{0.3} \mathrm{MnO}_{3+\delta}$ material (registered on $0.1^{\circ} \mathrm{C} \mathrm{min}{ }^{-1}$ heating) [26]. The cerium-substituted materials exhibit not only lower operating temperatures, with comparable, very narrow $\Delta T$ range but also relatively high oxygen storage capacity achievable in air. The maximum oxygen contents after cooling to room temperature with $1{ }^{\circ} \mathrm{C} \mathrm{min}^{-1}$ were 3.407 and 3.413 for $\mathrm{Y}_{0.7} \mathrm{~Tb}_{0.15} \mathrm{Ce}_{0.15} \mathrm{MnO}_{3+\delta}$ and $\mathrm{Y}_{0.6} \mathrm{~Tb}_{0.2} \mathrm{Ce}_{0.2} \mathrm{MnO}_{3+\delta}$, respectively (Fig. 3), i.e., the OSC $\approx 1900 \mu \mathrm{mol} \mathrm{O}$ $\mathrm{g}^{-1}$. For comparison, the performance of the $\mathrm{Y}_{1-x} \mathrm{R}_{x-}$ $\mathrm{MnO}_{3+\delta}$ family remained poor, e.g., with the oxygen content of only 3.05 for $\mathrm{Y}_{0.7} \mathrm{~Tb}_{0.3} \mathrm{MnO}_{3+\delta}$ in the same conditions, while measured with an order of magnitude slower cooling rate of $0.1{ }^{\circ} \mathrm{C} \mathrm{min}{ }^{-1}$ reached 3.25 [26].

The samples after oxidation in air followed by slow cooling to room temperature contain multiple phases, with a high amount of Hex3 and the remaining Hex1 being present (Fig. 4a). The existence of any of the Hex2 phase with the oxygen content $\delta \approx 0.41$, which is close to the one obtained in the TG measurements, was ruled out by the refinements. As seen in Fig. 4b, some peaks are left unassigned (marked with an asterisk sign), if such an assumption is considered. On the other hand, the overall high (average) oxygen content is consistent with the presence of the Hex3 phase $(\delta \approx 0.45)$, as indicated by the refinements. Also, as a high tendency of formation of the Hex1 

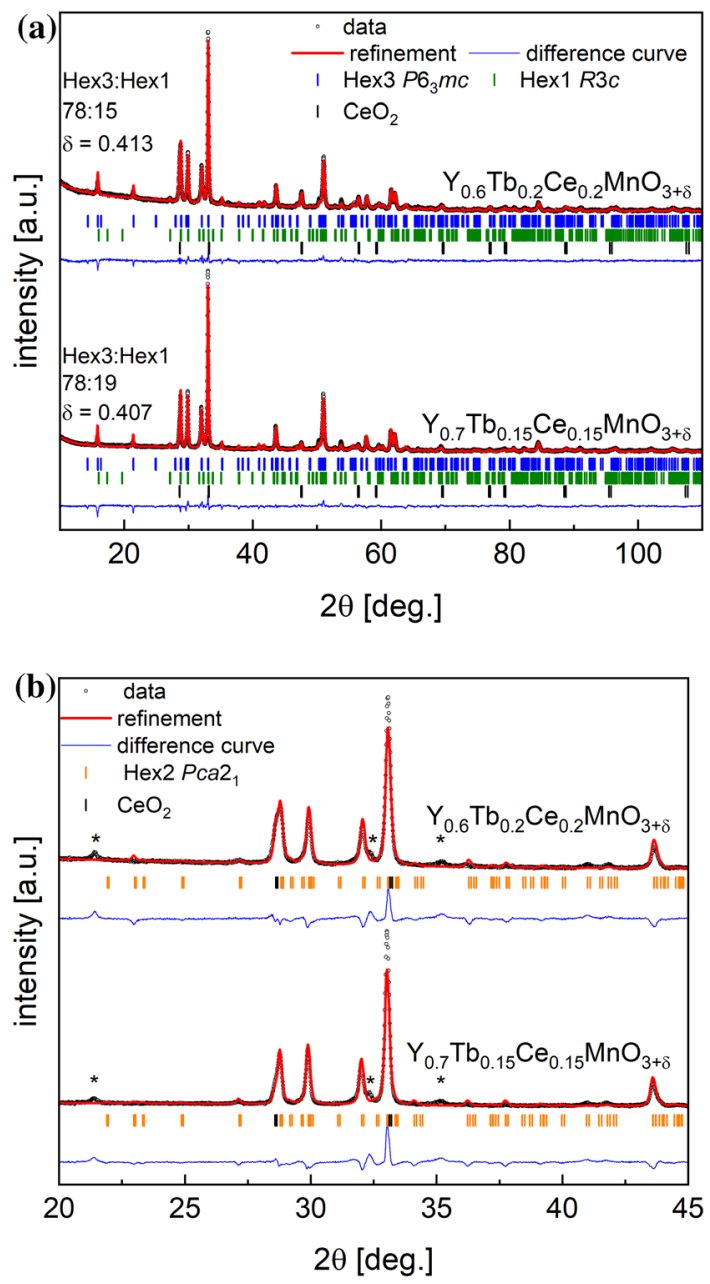

Figure 4 Room temperature $\mathrm{XRD}$ data for $\mathrm{Y}_{0.7} \mathrm{~Tb}_{0.15} \mathrm{Ce}_{0.15} \mathrm{MnO}_{3.407}$ and $\mathrm{Y}_{0.6} \mathrm{~Tb}_{0.2} \mathrm{Ce}_{0.2} \mathrm{MnO}_{3.413}$ after oxidation in air, refined with a the Hex3 and Hex1 phases, b the Hex 2 phase only, for the selected angular range, *other hexagonal phases.

phase $\delta \approx 0.28$ was shown in the synthesis process (Table 1), and likely also in the TG experiments (Fig. 3), its presence becomes visible. Despite the difficulty in deconvolution of the overlapping diffraction patterns of the two phases, the calculated excess oxygen amounts based on the weight ratio of the Hex 1 and Hex 3 phases, to $\delta \approx 0.369$ for $\mathrm{Y}_{0.6-}$ $\mathrm{Tb}_{0.2} \mathrm{Ce}_{0.2} \mathrm{MnO}_{3+\delta}$ and $\delta \approx 0.404$ for $\mathrm{Y}_{0.7} \mathrm{~Tb}_{0.15} \mathrm{Ce}_{0.15-}$ $\mathrm{MnO}_{3+\delta}$, are in good agreement with the TG data. This supports the correctness of the assumed phase compositions and the refinements. The lattice parameters of the dominant Hex3 and secondary Hex1 phases in the samples are summarized in Table 2.
For the oxidized materials, the direct comparison of the structural properties is more difficult because of different oxygen content in the Hex1 and Hex3 phases, as well as possible small variations of the oxygen stoichiometry in the Hex0 phase. However, it can be stated without ambiguity that the observed larger unit cell volume of the $\mathrm{Ce} / \mathrm{Tb}$-doped samples should be beneficial for the ionic transport because of geometric reasons related to the looser crystal structure. A closer look at the data also reveals that in comparison with the oxidized $\mathrm{Y}_{0.7} \mathrm{~Tb}_{0.3} \mathrm{MnO}_{3.45}$ (Table 1), both the studied samples show larger unit cell parameter $c$, which appears to be influencing oxygen transport in the $a b$-plane in the structure. This can be interpreted as structural flexibility along the $z$ direction.

To further elaborate on the oxidation state of the elements, the XPS measurements were conducted. As can be seen in Figs. $5 a, b$, for the reduced $Y_{0.7} T_{0.15-}$ $\mathrm{Ce}_{0.15} \mathrm{MnO}_{3}(\delta \approx 0)$ and the oxidized $\mathrm{Y}_{0.7} \mathrm{~Tb}_{0.15}$ $\mathrm{Ce}_{0.15} \mathrm{MnO}_{3+\delta}$ materials the survey spectra measured in the $0-1100 \mathrm{eV}$ binding energy range revealed the expected Ce3d, Mn2p O1s and Tb4d signals (with carbon signal being visible as well). A closer look at Ce3d spectra indicated several peaks (Fig. 5b), among which the peak at ca $917 \mathrm{eV}$ designated in the literature as a satellite $\mathrm{u}^{\prime \prime \prime}$ peak [42] is considered to be the signature of $\mathrm{Ce}^{4+}$ cations. However, the remaining part of the spectra also indicates the presence of $\mathrm{Ce}^{3+}$. It can be stated that cerium is most likely in a mixed-valent state $\mathrm{Ce}^{3+} / \mathrm{Ce}^{4+}$ in both samples. However, it is virtually impossible to evaluate the relative amount of both cations from the XPS studies. Nevertheless, it should also be stated that the change in the cerium signal between the oxidized and the reduced samples is rather small. While initially this can be interpreted that $\mathrm{Ce}$ is not active in the materials for the oxygen storage, the TG data presented in Fig. 3a, b suggest otherwise, as both samples are able to release considerably more oxygen in argon than in air, getting close to the stoichiometric composition at ca. $800{ }^{\circ} \mathrm{C}$. Importantly, both the samples slightly oxidized on cooling down to RT with the residual oxygen being present in Ar gas (ca. $10^{-5} \mathrm{~atm}$ of $5 \mathrm{~N} \mathrm{Ar}$ ). It is important to notice that direct evidence for $\mathrm{Ce}^{3+}$ (and no $\mathrm{Ce}^{4+}$ ) would require XPS studies at high temperatures.

There is a significant visible shift of the Mn2p signal (Fig. 5b) for the oxidized sample toward higher binding energies, which qualitatively can be 
Table 2 Lattice parameters of the Hex3 $P 6_{3} m c$ and Hex1 $R 3 c$ phase in $\mathrm{Y}_{0.7} \mathrm{~Tb}_{0.15} \mathrm{Ce}_{0.15} \mathrm{MnO}_{3.407}$ and $\mathrm{Y}_{0.6} \mathrm{~Tb}_{0.2} \mathrm{Ce}_{0.2} \mathrm{MnO}_{3.413}$ materials oxidized in air

\begin{tabular}{lllllll}
\hline Phase composition & Phase content $(\mathrm{wt} \%)$ & $a(\AA)$ & $c(\AA)$ & $V\left(\AA^{3}\right)$ & $R_{w p}(\%)$ & $\chi^{2}$ \\
\hline $\mathrm{Y}_{0.7} \mathrm{~Tb}_{0.15} \mathrm{Ce}_{0.15} \mathrm{MnO}_{3.407}^{\mathrm{a}}$ & Hex3 & $7.1570(1)$ & $11.1784(2)$ & $495.87(1)$ & 3.23 & 4.17 \\
& 78 & & & & \\
& Hex1 & $6.2113(2)$ & $33.2211(23)$ & $1109.95(10)$ & & \\
$\mathrm{Y}_{0.6} \mathrm{~Tb}_{0.2} \mathrm{Ce}_{0.2} \mathrm{MnO}_{3.413}^{\mathrm{b}}$ & 19 & & & & & \\
& Hex3 & $7.1548(1)$ & $11.1734(3)$ & $495.35(2)$ & 2.81 & 2.56 \\
& Hex1 & & & & \\
& 15 & $6.2097(3)$ & $33.2261(25)$ & $1109.56(11)$ & & \\
$\mathrm{Y}_{0.7} \mathrm{~Tb}_{0.3} \mathrm{MnO}_{3.45}^{\mathrm{c}}$ & $\mathrm{Hex3}$ & $7.1575(2)$ & $11.1552(4)$ & $494.92(3)$ & 2.9 & 4.03 \\
\hline
\end{tabular}

Both materials contain $\mathrm{CeO}_{2}$ contamination, as presented in Fig. $1 \mathrm{~b}$ in an amount

a $3 \mathrm{w} \%$

$\mathrm{b}_{8} \mathrm{wt} \%$

${ }^{\mathrm{c}}$ Data from [31]

interpreted as the oxidation of $\mathrm{Mn}^{3+}$ to $\mathrm{Mn}^{4+}$ [43]. The overall behavior can be therefore interpreted as follows: during heating in air up to $800{ }^{\circ} \mathrm{C}$, only $\mathrm{Mn}$ changes its oxidation state; however, cerium, which initially is at mixed $+3 /+4$ state, can also be reduced to +3 upon heating in Ar. This corresponds to the increased oxygen release. Because $\mathrm{Ce}^{3+}$ affinity to oxidize $\left(\right.$ to $\mathrm{Ce}^{4+}$ ) increases at lower temperatures, the material absorbs residual oxygen, so cerium can be oxidized even in Ar atmosphere, in which $\mathrm{Mn}$ remains largely as +3 .

To determine the temperature range ensuring effective operations, i.e., delivering the maximum change of the oxygen content (the oxygen storage capacity) in the TSA process, both samples were extensively tested under various temperature changes. The exemplary TSA results are presented in Fig. 6 for $\mathrm{Y}_{0.6} \mathrm{~Tb}_{0.2} \mathrm{Ce}_{0.2} \mathrm{MnO}_{3+\delta}$.

Even though the earlier presented experiments (Fig. 3) have shown that the working temperature differences can be quite low, in practice, due to the kinetic reasons, a larger $\Delta \mathrm{T}$ was required to induce sufficient oxygen content changes. Furthermore, the optimized time periods for oxidation and reduction may result in evenly shaped cycles, and the $45 \mathrm{~min}$ oxidation and 15 min reduction times were found to be more suitable for the majority of the conducted redox cycles. The averaged data from five consecutive cycles shown in Fig. 6 allowed to evaluate the practical OSC under particular conditions, as presented in Fig. 7a for $\mathrm{Y}_{0.7} \mathrm{~Tb}_{0.15} \mathrm{Ce}_{0.15} \mathrm{MnO}_{3+\delta}$ and Fig. $7 \mathrm{~b}$ for $\mathrm{Y}_{0.6} \mathrm{~Tb}_{0.2} \mathrm{Ce}_{0.2} \mathrm{MnO}_{3+\delta}$. The results are shown as a function of the oxidation and reduction temperatures.

The largest change of $\delta$ recorded in air for $\mathrm{Y}_{0.7-}$ $\mathrm{Tb}_{0.15} \mathrm{Ce}_{0.15} \mathrm{MnO}_{3+\delta}$ is 0.181 , which was obtained during the swing between 220 and $360{ }^{\circ} \mathrm{C}$. It should be noticed that in the selected measured ranges, the oxidation temperature does not influence the results considerably, while the higher OSC values are obtained at higher reduction temperatures. The reversible OSC is higher than $\Delta \delta=0.16$ achieved for $\mathrm{Y}_{0.7} \mathrm{~Tb}_{0.3} \mathrm{MnO}_{3+\delta}$ in $\mathrm{O}_{2}$ during the $45 \mathrm{~min}$ cycle $\left(300-350{ }^{\circ} \mathrm{C}\right)$ [26]. Interestingly, the Ce-substituted samples in the present study are working in a higher range of oxygen content (ca. $\mathrm{O}_{3.18} \leftrightarrow \mathrm{O}_{3.36}$ ) than the Ce-free material $\mathrm{Y}_{0.7} \mathrm{~Tb}_{0.3} \mathrm{MnO}_{3+\delta}$, where an efficient TSA cycling is achieved at ca. $\mathrm{O}_{3.0} \leftrightarrow \mathrm{O}_{3.2}$. Essentially, even though the TSA measurements for $\mathrm{Y}_{0.7-}$ $\mathrm{Tb}_{0.3} \mathrm{MnO}_{3+\delta}$ and the Ce-substituted samples look similar in terms of the registered capacity, the structural transformations and the involved crystal structures are different [26].

As demonstrated above, the hexagonal $\mathrm{YMnO}_{3}{ }^{-}$ based OSMs can effectively store/release oxygen by using the TSA method in air. In this work, an additional investigation was conducted regarding their applicability for operations involving oxygen partial pressure changes. The results of PSA processes conducted between air and Ar atmospheres (ca. $30 \mathrm{~min}$ 


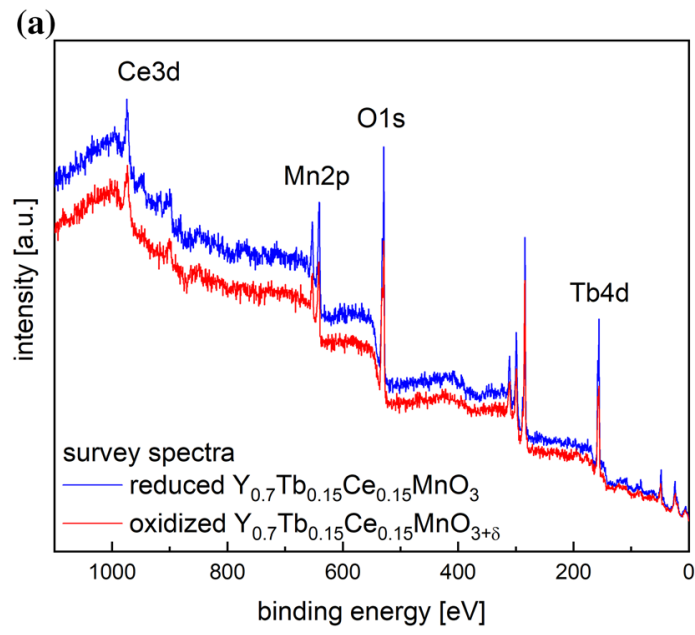

(b)

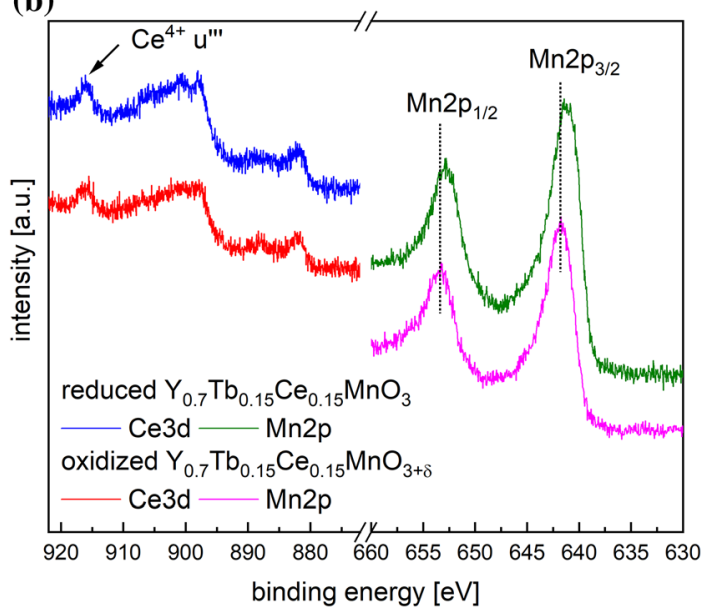

Figure 5 a XPS survey spectra for the reduced $\mathrm{Y}_{0.7} \mathrm{~Tb}_{0.15} \mathrm{Ce}_{0.15} \mathrm{MnO}_{3} \quad(\delta \approx 0) \quad$ and the oxidized $\mathrm{Y}_{0.7} \mathrm{~Tb}_{0.15} \mathrm{Ce}_{0.15} \mathrm{MnO}_{3+\delta}$. b Detailed data corresponding to $\mathrm{Ce} 3 \mathrm{~d}$ and $\mathrm{Mn} 2 \mathrm{p}$ regions.

per step) are presented in Fig. 8. The respective temperature of the experiment was chosen based on the result given in Fig. 3, i.e., as the temperature of the maximum oxygen content registered during the heating in air at $1^{\circ} \mathrm{C} \mathrm{min}^{-1}$ for the given sample. As can be seen, the attainable oxygen content changes are rather low, in the order of 0.05 for both samples. Achieving higher capacity in PSA might be possible when the operating temperature was further optimized. However, the goal of this study was just to check the materials' susceptibility to the PSA conditions, rather than focusing on improving the reversible oxygen storage capacity.

It should be emphasized that the laboratory studies of the candidate OSMs are commonly carried out only in either TSA or PSA conditions. Despite rather

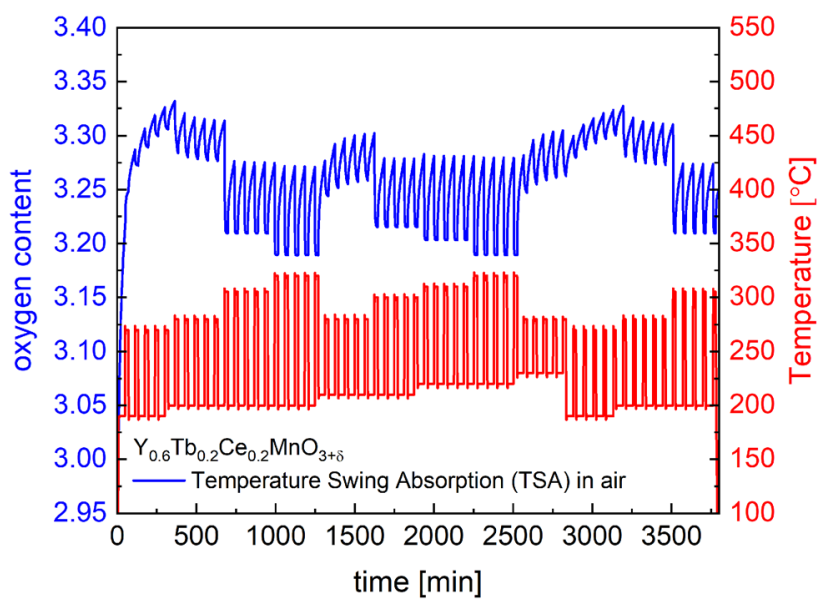

Figure 6 Selected TSA cycles (5 at each condition) recorded for $\mathrm{Y}_{0.6} \mathrm{~Tb}_{0.2} \mathrm{Ce}_{0.2} \mathrm{MnO}_{3+\delta}$ in air at various sets of temperatures (with 45 min oxidation and 15 min reduction times). Rapid heating and cooling of $100{ }^{\circ} \mathrm{C} \min ^{-1}$ were applied during the temperature change.

small OSC values obtained in PSA experiments, the fact that the considered material shows reversible changes in the oxygen content induced by both temperature swing and pressure swing processes has, to our best knowledge, never been reported for this class of materials. To further utilize the possibilities of TSA and PSA processes, the combined temperature pressure swing absorption (TPSA) process was developed, demonstrating larger changes of $\delta$ in a highly reversible manner, as presented in Fig. 9. The designed conditions were as follows: the 45 -min oxidation period at $220{ }^{\circ} \mathrm{C}$ in $\mathrm{O}_{2}$ or air atmospheres, and the reduction at $360{ }^{\circ} \mathrm{C}$ in $\mathrm{N}_{2}$ flow for $15 \mathrm{~min}$. Because of the uneven shape of the registered curves, indicating ongoing changes in oxidation and reduction capacities, the direct readout of OSC is difficult from the curves. Therefore, the oxygen content change for every cycle is presented separately in Fig. 9c. Noticeably, the OSC values remain relatively stable within 5 consecutive cycles.

For both the materials, the swing between nitrogen and oxygen yields a higher capacity than that between nitrogen and air (Fig. 9c). Further, in the range of $220-360{ }^{\circ} \mathrm{C}$ and air- $\mathrm{N}_{2}$ conditions, the oxygen content change reaches $\Delta \delta=0.26$, corresponding to $1200 \mu \mathrm{mol} \mathrm{O} \mathrm{g}^{-1}$ ). Theoretically, the capacity for $\mathrm{Y}_{1-x} \mathrm{R}_{x} \mathrm{MnO}_{3+\delta}$ materials is limited by $\delta \approx 0.45$ for the Hex3 $\mathrm{Pb}_{3} \mathrm{Cm}$ structure. In the measurements presented in Fig. 3, the highest registered practical capacity for the studied sample was related to the 
(a)

TSA $\mathrm{Y}_{0.7} \mathrm{~Tb}_{0.15} \mathrm{Ce}_{0.15} \mathrm{MnO}_{3+\delta}$ in air 45 min oxi. 15 min red.

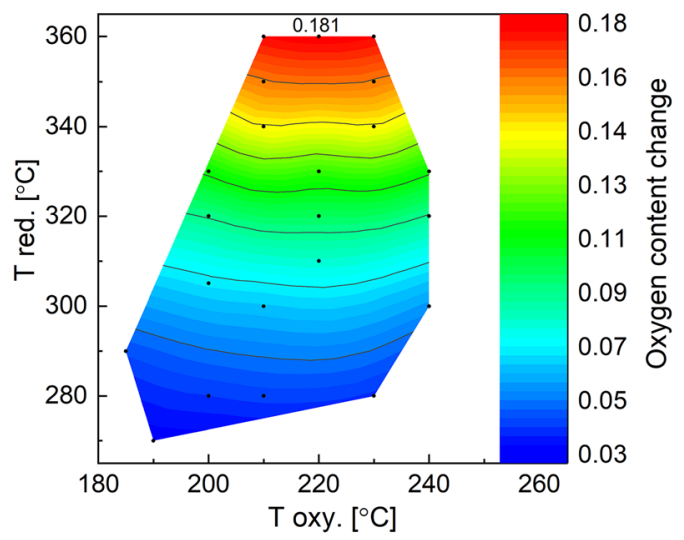

(b)

TSA $\mathrm{Y}_{0.6} \mathrm{~Tb}_{0.2} \mathrm{Ce}_{0.2} \mathrm{MnO}_{3+\delta}$ in air 45 min oxi. 15 min red.

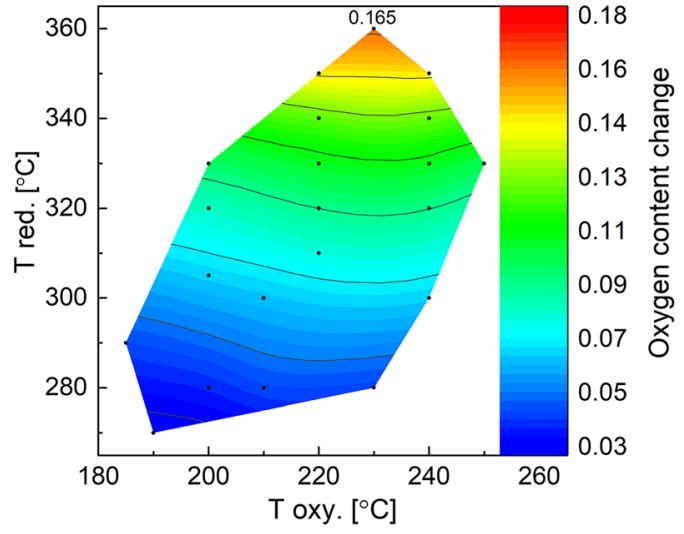

Figure 7 Oxygen content change data plotted in the form of a matrix, based on the results of the TSA process in air conducted at $T_{\text {ox }}$ for oxygen incorporation and $T_{\text {red }}$ for oxygen release (45 min oxidation and 15 min reduction) for a $\mathrm{Y}_{0.7} \mathrm{~Tb}_{0.15} \mathrm{Ce}_{0.15} \mathrm{MnO}_{3+\delta}$ and $\mathbf{b} \mathrm{Y}_{0.6} \mathrm{~Tb}_{0.2} \mathrm{Ce}_{0.2} \mathrm{MnO}_{3+\delta}$.

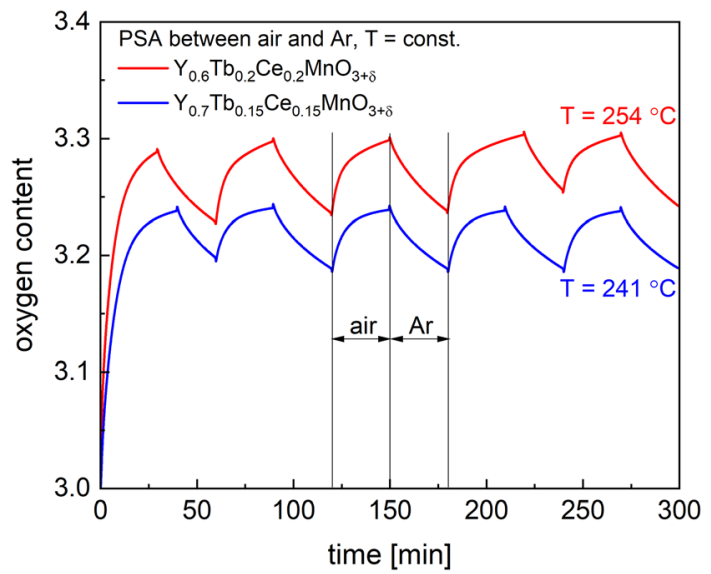

Figure 8 Oxygen content changes during PSA cycles between air and $\mathrm{Ar}$ for $\mathrm{Y}_{0.7} \mathrm{~Tb}_{0.15} \mathrm{Ce}_{0.15} \mathrm{MnO}_{3+\delta}$ at $241{ }^{\circ} \mathrm{C}$ and $\mathrm{Y}_{0.6} \mathrm{~Tb}_{0.2} \mathrm{Ce}_{0.2} \mathrm{MnO}_{3+\delta}$ at $254{ }^{\circ} \mathrm{C}$. oxygen content increase up to $\delta=0.41$. Therefore, the $\Delta \delta=0.26$ achieved in the TPSA study constitutes almost $63 \%$ of the total registered capacity.
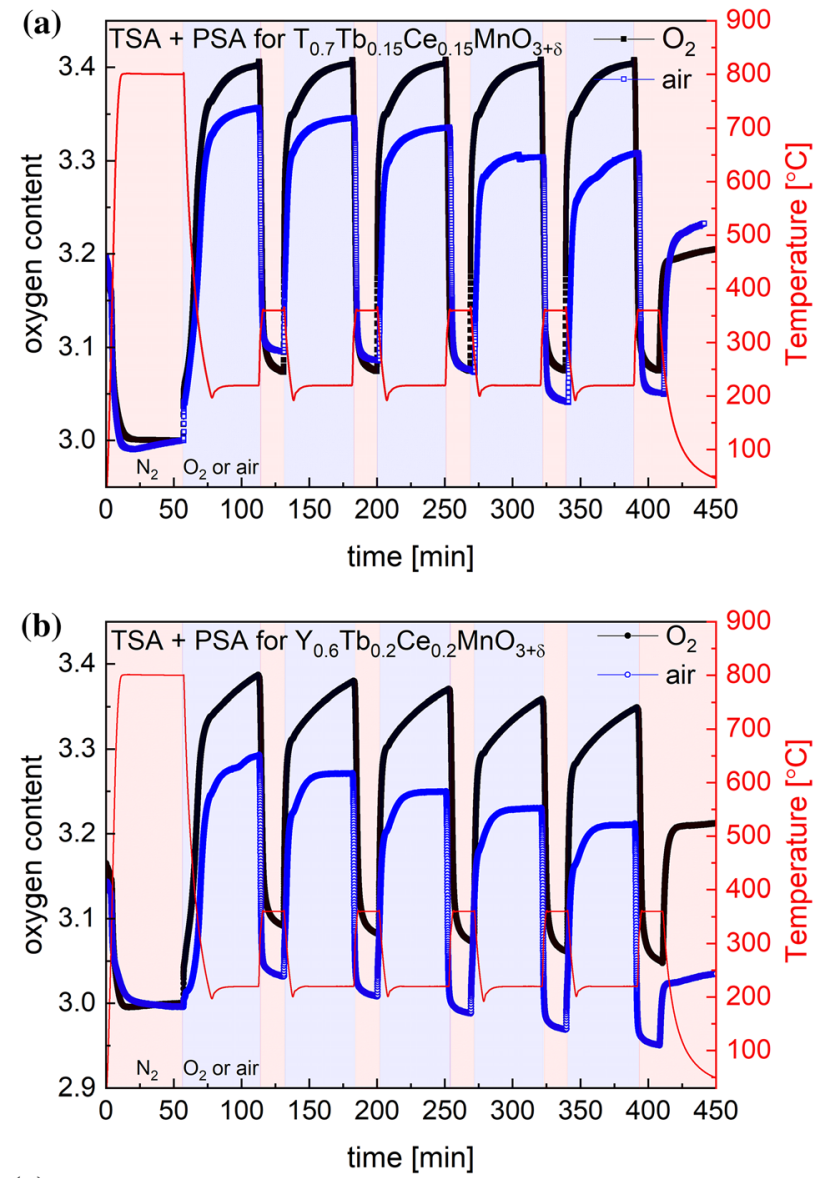

(c)

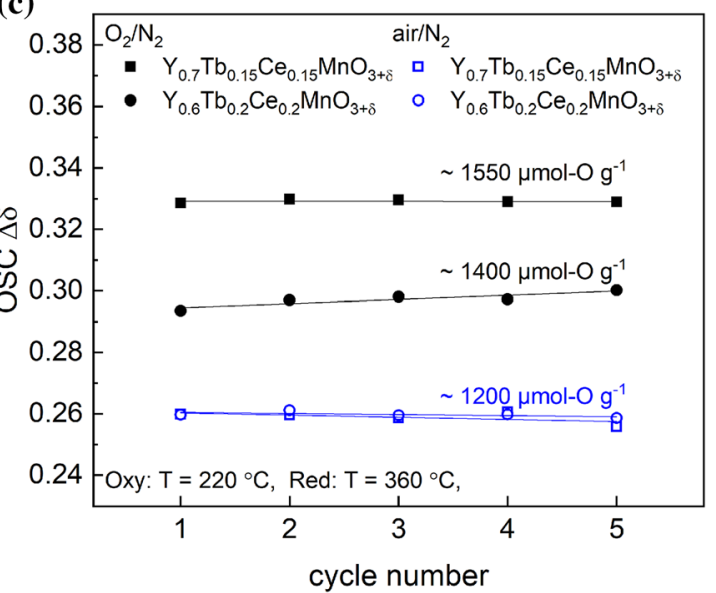

Figure 9 Oxygen content changes induced by combined TSA and PSA (TPSA) processes for a $\mathrm{Y}_{0.7} \mathrm{~Tb}_{0.15} \mathrm{Ce}_{0.15} \mathrm{MnO}_{3+\delta}$ and b $\mathrm{Y}_{0.6} \mathrm{~Tb}_{0.2} \mathrm{Ce}_{0.2} \mathrm{MnO}_{3+\delta}$ during swing between 220 and $360{ }^{\circ} \mathrm{C}$, and using $\mathrm{N}_{2}$ as the reducing gas, while either $\mathrm{O}_{2}$ or air as the oxidizing one. c Oxygen storage capacity, calculated for the respective TPSA cycles. 
In PSA and TSA processes, the changing conditions (gradient) of pressure and of temperature separately cause changes in the oxygen stoichiometry of the samples. In the combined TPSA process, those effects are superposed, and therefore, the registered capacity is naturally greater than in the individual TSA or PSA process. As documented above, the superior performance observed for the $\mathrm{Tb} / \mathrm{Ce}$-containing $\mathrm{Y}_{1-x}(\mathrm{~Tb} /$ Ce) ${ }_{x} \mathrm{MnO}_{3+\delta}$ materials in TSA and TPSA processes with oxidation in air promises their application in the air enrichment and oxygen production technologies.

\section{Conclusions}

Partial substitution of yttrium by equal amounts of $\mathrm{Tb}$ and $\mathrm{Ce}$ in $\mathrm{Y}_{1-x}(\mathrm{~Tb} / \mathrm{Ce})_{x} \mathrm{MnO}_{3+\delta}$ led to the formation of the desired hexagonal materials, with only a trace amount of $\mathrm{CeO}_{2}$ impurity. As-synthesized samples of these materials exhibited excess oxygen in their structure, which can be interpreted as a very strong affinity of the compounds for oxidation. A reduction step at $800{ }^{\circ} \mathrm{C}$ in $\mathrm{Ar}$ was necessary to obtain oxygen-stoichiometric samples. It was found that the temperature needed for oxygen incorporation in the Hex0 phase is very low for both compositions $x=0.15$ and 0.20 , with the effective oxidation occurring as low as $185-195{ }^{\circ} \mathrm{C}$ in air and the maximum measured capacity of $1900 \mu \mathrm{mol} \mathrm{O} \mathrm{g}{ }^{-1}$. The samples oxidized at lower temperatures release oxygen quite rapidly at $280-290{ }^{\circ} \mathrm{C}$ and higher temperatures. During the TSA process in air, a swing between 220 and $360{ }^{\circ} \mathrm{C}$ yielded the highest oxygen storage capacity of $860 \mu \mathrm{mol} \mathrm{O} \mathrm{g}{ }^{-1}$ for $\mathrm{Y}_{0.7} \mathrm{~Tb}_{0.15-}$ $\mathrm{Ce}_{0.15} \mathrm{MnO}_{3+\delta}$ and a swing between 230 and $360{ }^{\circ} \mathrm{C}$ for $\mathrm{Y}_{0.6} \mathrm{~Tb}_{0.2} \mathrm{Ce}_{0.2} \mathrm{MnO}_{3+\delta}$ yielded $760 \mu \mathrm{mol} \mathrm{O} \mathrm{g}^{-1}$. Both samples exhibited rather small changes in the oxygen content during the PSA processes between air and $\mathrm{Ar}$ at $241{ }^{\circ} \mathrm{C}$ and $254{ }^{\circ} \mathrm{C}$ for the former and latter, respectively. The combined TSA and PSA (TPSA) approach, utilizing the superposed effect of the temperature and pressure changes, revealed the significant performance of both the materials during the swing conducted at $220-360{ }^{\circ} \mathrm{C}$ and $\mathrm{O}_{2}-\mathrm{N}_{2}$ conditions, and also a promising performance of both the materials when the air was used for oxidation. The reversible OSC of ca. $1200 \mu \mathrm{mol} \mathrm{O} \mathrm{g}{ }^{-1}$ was achieved in such operating conditions. It can be summarized that the $\mathrm{Y}_{1-x}(\mathrm{~Tb} / \mathrm{Ce})_{x} \mathrm{MnO}_{3+\delta}$ exhibit superior oxygen storage-related properties among known compositions for the whole family of hexagonal $\mathrm{Y}_{1-x} \mathrm{R}_{x} \mathrm{MnO}_{3+\delta}$. In particular, they seem suitable for air enrichment and/or the oxygen production using the TSA and/or TPSA methods.

\section{Acknowledgements}

This work was supported by JSPS KAKENHI Grant No. JP18K13997, and by Council for Science, Technology and Innovation (CSTI), Cross-ministerial Strategic Innovation Promotion Program (SIP), "Energy systems toward a decarbonized society" (Funding agency: JST). The authors would like to thank Chayanaphat Chokradjaroen of Nagoya University for the XPS measurements. Work at Polish Academy of Sciences was supported by the Polish NCN through Grant No. 2018/31/B/ST5/03024.

Open Access This article is licensed under a Creative Commons Attribution 4.0 International License, which permits use, sharing, adaptation, distribution and reproduction in any medium or format, as long as you give appropriate credit to the original author(s) and the source, provide a link to the Creative Commons licence, and indicate if changes were made. The images or other third party material in this article are included in the article's Creative Commons licence, unless indicated otherwise in a credit line to the material. If material is not included in the article's Creative Commons licence and your intended use is not permitted by statutory regulation or exceeds the permitted use, you will need to obtain permission directly from the copyright holder. To view a copy of this licence, visit http://creativecommons.org/licen ses $/$ by $/ 4.0 /$.

\section{References}

[1] McWhirter JR (2019) The use of high-purity oxygen in the activated sludge, vol 1. CRC Press, Boca Raton

[2] Asano R, Mathai SC, Macdonald PS, Newton PJ, Currow DC, Phillips J, Yeung W-F, Davidson PM (2020) Oxygen use in chronic heart failure to relieve breathlessness: a systematic revive. Heart Fail Rev 25(2):195-205

[3] Guo H, Yin S, Yu Q, Yang X, Huang H, Yang Y, Gao F (2018) Iron recovery and active residue production from basic oxygen furnace (BOF) slag for supplementary cementitious materials. Resour. Conserv. Recy. 129:209-218 
[4] Dalena F, Senatore A, Marino A, Gordano A, Basile M, Basile A (2018) Chapter 1 - methanol production and applications: an overview. Methanol science and engineering. Elsevier, Amsterdam, pp 3-28

[5] Tan X, Li K (2007) Oxygen production using dense ceramic hollow fiber membrane modules with different operating modes. AIChE J 53:838-845

[6] Cheng Y, Zhao H, Teng D, Li F, Lu X, Ding W (2008) Investigation of $\mathrm{Ba}$ fully occupied $\mathrm{A}$-site $\mathrm{BaCo}_{0.7} \mathrm{Fe}_{0.3-x}$ $\mathrm{Nb}_{x} \mathrm{O}_{3-\delta}$ perovskite stabilized by low concentration of $\mathrm{Nb}$ for oxygen permeation membrane. J Membr Sci 322:484-490

[7] Lu Y, Zhao H, Chang X, Du X, Li K, Ma Y, Yi S, Du Z, Zheng K, Świerczek K (2016) Novel cobalt-free $\mathrm{BaFe}_{1-x \text { - }}$ $\mathrm{Gd}_{x} \mathrm{O}_{3+\mathrm{d}}$ perovskite membranes for oxygen separation. J Mater Chem A 4:10454-10466

[8] Prosser NM, Shah MM (2011) Oxy-fuel combustion for power generation and carbon dioxide $\left(\mathrm{CO}_{2}\right)$ capture. Woodhead Publishing Series in Energy, pp 195-227

[9] Fu Y, Liu Y, Yang X, Li Z, Jiang L, Zhang C, Wang H, Yang RT (2019) Thermodynamic analysis of molecular simulations of $\mathrm{N}_{2}$ and $\mathrm{O}_{2}$ adsorption on zeolites under plateau special conditions. Appl Surf Sci 480:868-875

[10] Santos JC, Cruz P, Regala T, Magalhães FD, Mendes A (2007) High-purity oxygen production by pressure swing adsorption. Ind Eng Chem Res 46:591-599

[11] Saha D, Kienbaum MJ (2019) Role of oxygen, nitrogen and sulfur functionalities on the surface of nanoporous carbons in $\mathrm{CO}_{2}$ adsorption: a critical review. Microporous Mesoporous Mater 287:29-55

[12] Kašpar J, Fornasiero P (2013) Nanostructured materials for advanced automotive de-pollution catalysts. J Solid State Chem 171:19-29

[13] Di Monte R, Kašpar J (2004) On the role of oxygen storage in three-way catalysis. Top Catal 28:47-57

[14] Motohashi T, Ueda T, Masubuchi Y, Takiguchi M, Setoyama T, Oshima K, Kikkawa S (2010) Remarkable oxygen intake/ release capability of $\mathrm{BaYMn}_{2} \mathrm{O}_{5+\delta}$ : applications to oxygen storage technologies. Chem Mater 22:3192-3196

[15] Klimkowicz A, Świerczek K, Rząsa T, Takasaki A, Dabrowski B (2016) Oxygen storage properties and catalytic activity of layer ordered perovskites $\mathrm{BaY}_{1-x} \mathrm{Gd}_{x} \mathrm{Mn}_{2} \mathrm{O}_{5+\delta}$. Solid States Ionics 288:43-47

[16] Klimkowicz A, Świerczek K, Yamazaki T, Takasaki A (2016) Enhancement of the oxygen storage properties of $\mathrm{BaPrMn}_{2} \mathrm{O}_{5+\delta}$ and $\mathrm{BaSmMn}_{2} \mathrm{O}_{5+\delta}$ oxides by a high-energy milling. Solid State Ionics 298:66-72

[17] Nazarpoor Z, Golden SJ (2016) Clean Diesel Technologies, Inc., Thermally stable compositions of OSM free of rare earth metals, US Patent USOO9486784B2
[18] Bahout M, Managutti PB, Dorcet V, Le Gal La A, Salle S, Paofai T Hansen (2020) In situ exsolution of Ni particles on the $\mathrm{PrBaMn}_{2} \mathrm{O}_{5}$ SOFC electrode material monitored by high temperature neutron powder diffraction under hydrogen. J Mater Chem A 8:3590-3597

[19] Zhang Y, Zhao H, Du Z, Świerczek K, Li Y (2019) Highperformance $\mathrm{SmBaMn}_{2} \mathrm{O}_{5+\delta}$ electrode for symmetrical solid oxide fuel cell. Chem Mater 31(10):3784-3793

[20] Tonus F, Bahout M, Dorcet V, Gauthier GH, Paofai S, Smith RI, Skinner SJ (2016) Redox behavior of the SOFC electrode candidate $\mathrm{NdBaMn}_{2} \mathrm{O}_{5+\delta}$ investigated by high-temperature in situ neutron diffraction: first characterisation in real time of an $\mathrm{LnBaMn}_{2} \mathrm{O}_{5.5}$ intermediate phase. J Mater Chem A 4:11635-11647

[21] Macias MA, Sandoval MV, Martinez NG, Vázquez-Cuadriello S, Suescun L, Roussel P, Świerczek K, Gauthier GH (2016) Synthesis and preliminary study of $\mathrm{La}_{4} \mathrm{BaCu}_{5} \mathrm{O}_{13+\delta}$ and $\mathrm{La}_{6.4} \mathrm{Sr}_{1.6} \mathrm{Cu}_{8} \mathrm{O}_{20 \pm \delta}$ ordered perovskites as SOFC/PCFC electrode materials. Solid State Ionics 288:61-67

[22] Jeamjumnunja K, Gong W, Makarenko T, Jacobson AJ (2015) A determination of the oxygen non-stoichiometry of the oxygen storage material $\mathrm{YBaMn}_{2} \mathrm{O}_{5+\delta}$. J Solid State Chem 230:397-403

[23] Abughayada C, Dabrowski B, Kolesnik S, Brown DE, Chmaissem O (2015) Characterization of oxygen storage and structural properties of oxygen-loaded hexagonal $\mathrm{RMnO}_{3+\delta}$ $(\mathrm{R}=\mathrm{Ho}$, Er, and Y). Chem Mater 27(18):6259-6267

[24] Vieten J, Bulfin B, Call F, Lange M, Schmücker M, Francke A, Roeb M, Sattler C (2016) Perovskite oxides for application in thermochemical air separation and oxygen storage. J Mater Chem A 4:13652-13659

[25] Bulfin B, Vieten J, Starr DE, Azarpira A, Zachäus C, Hävecker M, Skorupska K, Schmücker M, Roeb M, Sattler $\mathrm{C}$ (2017) Redox chemistry of $\mathrm{CaMnO}_{3}$ and $\mathrm{Ca}_{0.8} \mathrm{Sr}_{0.2} \mathrm{MnO}_{3}$ oxygen storage perovskites. J Mater Chem A 5:7912-7919

[26] Karppinen M, Yamauchi H, Otani S, Fujita T, Motohashi T, Huang Y-H, Valkeapää M, Fjellvåg H (2006) Oxygen nonstoichiometry in $\mathrm{YBaCo}_{4} \mathrm{O}_{7+\delta}$ : large low-temperature oxygen absorption/desorption capability. Chem Mater $18: 490-494$

[27] Motohashi T, Hirano Y, Masubuchi Y, Oshima K, Setoyama T, Kikkawa S (2013) Oxygen storage capability of brownmillerite-type $\mathrm{Ca}_{2} \mathrm{AlMnO}_{5+\delta}$ and its application to oxygen enrichment. Chem Mater 25(3):372-377

[28] Dou J, Krzystowczyk E, Mishra A, Liu X, Li F (2018) Perovskite promoted mixed cobalt-iron oxides for enhanced chemical looping air separation. ACS Sustain Chem Eng 6:15528-15540

[29] Xu M, Wu H-C, Lin YS, Deng S (2018) Simulation and optimization of pressure swing adsorption process for high- 
temperature air separation by perovskite sorbents. Chem Eng J 354:62-74

[30] Parkkima O, Yamauchi H, Karppinen M (2013) Oxygen storage capacity and phase stability of variously substituted $\mathrm{YBaCo}_{4} \mathrm{O}_{7+\delta}$. Chem Mater 25:599-604

[31] Klimkowicz A, Cichy K, Chmaissem O, Dabrowski B, Poudel B, Świerczek K, Taddei KM, Takasaki A (2019) Reversible oxygen intercalation in hexagonal $\mathrm{Y}_{0.7} \mathrm{~Tb}_{0.3-}$ $\mathrm{MnO}_{3+\mathrm{d}}$ : toward oxygen production by temperature-swing absorption in air. J Mater Chem A 7:2608-2618

[32] Klimkowicz A, Świerczek K, Kobayashi S, Takasaki A, Allahyani W, Dabrowski B (2018) Improvement of oxygen storage properties of hexagonal $\mathrm{YMnO}_{3+\mathrm{d}}$ by microstructural modifications. J Solid State Chem 258:471-476

[33] Świerczek K, Klimkowicz A, Nishihara K, Kobayashi S, Takasaki A, Alanizy M, Kolesnik S, Dabrowski B, Seonge S, Kange J (2017) Oxygen storage properties of hexagonal $\mathrm{HoMnO}_{3+\mathrm{d}}$. Phys Chem Chem Phys 19:19243-19251

[34] Skjærvø SH, Wefring ET, Nesdal SK, Gaukås NH, Olsen GH, Glaum J, Tybell T, Selbach SM (2016) Interstitial oxygen as a source of p-type conductivity in hexagonal manganites. Nat Commun 7:13745

[35] Asakura Y, Miyake A, Otomo M, Yin S (2020) Improvement of the $\mathrm{O}_{2}$ storage/release rate of $\mathrm{YMnO}_{3}$ nanoparticles synthesized by the polymerized complex method. Dalton Trans 49:966-971
[36] Database of Ionic Radii: http://abulafia.mt.ic.ac.uk/shannon/ ptable.php, accessed on 06 April 2020

[37] Parkkima O, Malo S, Hervieu M, Rautama EL, Karppinen M (2015) New $\mathrm{RMnO}_{3+\delta}(\mathrm{R}=\mathrm{Y}, \mathrm{Ho} ; \delta \approx 0.35)$ phases with modulated structure. J Solid State Chem 221:109-115

[38] West AR (2014) "Solid state chemistry and its applications", second edition, 2nd, Student edn. Wiley, Chichester

[39] Larson AC, von Dreele RB (2004) GSAS general structure analysis system. Los Alamos National Laboratory Unclassified Report, 86-748

[40] Toby HB (2001) EXPGUI, a graphical user interface for GSAS. J Appl Crystallogr 34:210-213

[41] Li P, Chena X, Li Y, Schwank JW (2019) A review on oxygen storage capacity of $\mathrm{CeO}_{2}$-based materials: influence factors, measurement techniques, and applications in reactions related to catalytic automotive emissions control. Catal Today 327:90-115

[42] Bêche E, Charvin P, Perarnau D, Abanades S, Flamant G (2008) Ce 3d XPS investigation of cerium oxides and mixed cerium oxide $\left(\mathrm{Ce}_{x} \mathrm{Ti}_{\mathrm{y}} \mathrm{O}_{\mathrm{z}}\right)$. Surf Interface Anal 40:264-267

[43] Junta JL, Hochella MF (1994) Manganese (II) oxidation at mineral surfaces: a microscopic and spectroscopic study. Geochim Cosmochim Acta 58:4985-4999

Publisher's Note Springer Nature remains neutral with regard to jurisdictional claims in published maps and institutional affiliations. 